\title{
In memoriam Noel M. Swerdlow
}

We have recently received the sad news that Noel Swerdlow (1941-2021) passed away this Saturday 24 July. Noel was a leading historian of science who specialized in premodern astronomy from the Babylonian astronomical ephemerides of the Hellenistic period across the entire range of Western astronomy to the Renaissance, focusing on the works of Regiomontanus, Copernicus, Tycho Brahe, Kepler, and Galileo.

He received a B.A. (1964) from the University of California, Los Angeles, and an M.A. (1967) and Ph.D. (1968) from Yale University. Turning from the study of medieval music to astronomy, Noel's doctoral dissertation was titled "Ptolemy's Theory of the Distances and Sizes of the Planets: A Study of the Scientific Foundations of Medieval Cosmology" (Yale University, 1968). He produced a translation and commentary on Copernicus' early astronomical work, The Commentariolus (1973), and co-authored with the late O. Neugebauer Mathematical Astronomy in Copernicus's De Revolutionibus (1984). Noel is also the author of The Babylonian Theory of the Planets (1998). His many articles constitute an important body of work dealing with the technical aspects of mathematical astronomical theory and its centrality to the history of science.

Noel was a professor in the Department of Astronomy and Astrophysics and in the Department of History at the University of Chicago from 1982 until 2008. He was a member of the Institute for Advanced Study $(1973,1985)$ in Princeton, New Jersey, and a MacArthur fellow (class of 1988). In 1998, he was elected to membership in the American Philosophical Society. In 2008 he retired to Caltech as visiting associate in history in the Division of the Humanities and Social Sciences.

Noel was also an accomplished pianist and had a detailed knowledge of the Romantic tradition, not only of the piano oeuvres of Beethoven, Brahms, Schuman, Schubert, Liszt and others, but also of chamber and orchestral music as well as of opera, about which he was a true specialist. He taught a legendary course on Wagner's Ring of the Niebelungen at the University of Chicago. 
Noel's wife of 32 years, Nadia Swerdlow of Sierra Madre, CA, and Noel's son from a previous marriage, Dorian, were with him to the end. To them we extend our deepest condolences.

As Noel's colleagues, students, and friends, we learned much from his rigorous approach and the broad understanding and the depth of his scholarship that stemmed from his rigor and exactitude. For all he gave us, we are profoundly grateful.

The Editors 